\title{
Öğretmenlerin Okuduğunu Anlama Düzeyleri: Temel Eğitim Okullarında Çalışan Öğretmenler Üzerine Bir Araştırma
}

\author{
Ali BALTACI* \\ • Geliş Tarihi: 13.04.2020 • Kabul Tarihi: 13.07.2020 • Çevrimiçi Yayın Tarihi: 11.10.2020
}

\section{$\ddot{\mathbf{O} z}$}

$\mathrm{Bu}$ çalışmanın amacı, temel eğitim okullarında (ilk ve ortaokul) görev yapan öğretmenlerinin okuduğunu anlama düzeylerinin belirlenmesidir. Araştırma betimsel tarama modeli ile kurgulanmıştır. Ankara' da çalışmakta olan 1415 öğretmen araştırmanın örneklem grubunu oluşturmaktadır. Çalışmada araştırmacı tarafından geliştirilen ‘Okuduğunu Anlamayı Değerlendirme Ölçeği' kullanılmıştır. Ölçme aracına ait puanlama anahtarının güvenilirliği Krippendorff'un alfa $(\alpha)$ katsayısı, Cohen'in kappa ( $\kappa)$ katsayısı, Pearson moment çarpım katsayısı kullanılmıştır. Veriler, betimsel istatistik teknikleri kullanılarak çözümlenmiştir. Araştırma sonuçlarına göre, öğretmenler öyküleyici metinleri 'iyi’, bilgilendirici metinleri 'zayıf' düzeyde anlamaktadır. Genel olarak öğretmenler, okuduklarını 'orta' düzeyde anlamaktadırlar. Bunun yanında öğretmenlerin demografik özellikleriyle (cinsiyet, mesleki kıdem, branş ve öğrenim durumları) okuduğunu anlama düzeyi arasında anlamlı farklılık bulunmaktadır. Erkek, lisansüstü mezunu ve mesleki kıdemi fazla olan öğretmenler, okuduklarını daha fazla anlamaktadırlar. Ayrıca, genel okuduğunu anlama düzeyi, Türkçe öğretmenlerinde "iyi"; beden eğitimi, görsel sanatlar, müzik ile teknoloji ve tasarım dallarındaki öğretmenlerinde "zayıf"; bilişim teknolojileri, din kültürü ve ahlak bilgisi, fen ve teknoloji, matematik, okul öncesi, rehberlik, sınıf, sosyal bilgiler ve yabancı dil öğretmenlerinde "orta" düzeyde olduğu belirlenmiştir. Bu araştırmada öğretmenlerin okuduğunu anlama düzeylerindeki yetersizlik görünür kılınmıştır. Alanyazındaki önemli bir boşluğa işaret eden bu çalışma, okuduğunu anlama çalışmalarının hizmet öncesi ve hizmetiçi dönemi kapsayacak şekilde genişletilmesi açısından önem taşımaktadır.

Anahtar sözcükler: okuma, okuduğunu anlama, okuduğunu anlama düzeyi, öğretmen

Atıf:

Baltac1, A. (2021). Öğretmenlerin okuduğunu anlama düzeyleri: temel eğitim okullarında çalışan öğretmenler üzerine bir araştırma. Pamukkale Üniversitesi Eğitim Fakültesi Dergisi, 51, 236261.doi:10.9779/pauefd.719811.

\footnotetext{
* Dr.Öğrt. Üyesi, Mersin Üniversitesi, alibaltaci@mersin.edu.tr, ORCID: 0000-0003-2550-8698
} 


\section{Giriș}

Her kişi bir dil içine doğar; bu dil onun yaşantısına yön verir. Heidegger, dilin düşüncenin evi ve insan yaşamının temel belirleyicisi olduğunu; insanın düşünsel dünyasının genişliğinin, kendi dilinin sınırları kadar olabileceğini savunur (Heidegger, 2002). Kişi dünyasını dil ile kurmakta ve dil, insan yaşamına yön veren temel unsur olarak kabul edilmektedir (Berger ve Luckmann, 2005). Kişinin diğerleriyle gerçekleştirdiği sözlü veya yazılı iletişimin tümü bir dilin sınırları dâhilindedir. Kişinin toplumla sağlıklı ilişkiler kurması dinleme, konuşma, okuma ve yazmanın birleşimi olarak ifade edilen dil becerilerinin gelişmişliğiyle doğrudan ilişkilidir. Okuma, yazılı harf ve sembolleri seslendirmekten ziyade, onlara bir anlam yükleme ve metindeki mesajı doğru olarak kavrama sürecidir (Habermas, 2001) . Bu süreç kişinin kendisi ve çevresinde arasında var olan ilişkilere bağlı olarak gelişir. Gelişimi kişinin aile ve yakın çevresinde başlayan dil becerileri, yaşantı boyunca sistematik biçimde ilerler.

Eğitime yapılan yatırımlara rağmen Türk öğrencilerin okuduğunu anlama düzeyi uluslararası değerlendirmelerde istenen seviyede değildir. Bu durum kamusal alanda önemli bir tartışma konusudur (PISA, 2015; MEB, 2019; Baltacı, 2017; Kurnaz ve Akaydın, 2015). Ayrıca öğrencilerin dil becerilerine katkı sağlayacak konumda olan öğretmenlerin nitelik ve yeterlikleri de sorgulanmaktadır. Öğrencilerin yeterli dil becerilerini kazanması için öğretmenlerin de nitelikli dil becerileriyle donanmış olması gereklidir. $\mathrm{Bu}$ açıdan öğretmenlerin okuduğunu anlama düzeyinin belirlenmesi, hem öğrencilerin dil gelişimine katkı sağlarken hem de onların toplumsal düzene uyumunu kolaylaştıracaktır. Bu bağlamda öğretmenlerin temel yeterliklerinin belirlenmesi kapsamında onların okuduğunu anlama düzeylerinin tespit edilmesi elzemdir.

Eğitim sisteminin amaçlarından birisi, öğretimin ilk yıllarından itibaren öğrencilerin okuduğunu anlama becerilerinin geliştirilmesidir (Çam, 2006). Belirli bir hızda anlayarak okumanın, öğrencinin akademik başarısı üzerinde etkili olduğu bilgisinden hareketle öğrencinin okuduğunu anlama becerisinin geliştirilmesi, öğrenme durumlarındaki verimin artmasına neden olabilir (Suna, 2005). Ayrıca okuma becerilerinin geliştirilmesi yeni öğrenmeler için önemli bir zemin oluşturulmasına katkı sunabilir (Bügel ve Buunk, 1996; Tayşi, 2007). Bir metni akıcı ve hatasız okuyabilen, okuduğunu yeterli düzeyde anlayabilen, sözcük dağarcığı gelişmiş bir öğrencinin, bu özelliklere sahip olmayanlara göre yeni bilgileri öğrenmesi daha kolay ve akademik başarısı daha yüksek olabilir (Odabaş, Odabaş ve Polat, 2008; Çelenk ve Çalışkan, 2004). Başaran (2013) ve Ungan (2008), öğrenmeye ayrılan zaman 
göz ardı edildiğinde, kişilerin bilgi düzeyindeki öğrenme durumlarının sadece okuduğunu anlama düzeyi incelenerek belirlenebileceğini bildirmişlerdir. Buna karşın okuduğunu anlama, kişinin temel iletişim becerileri ve toplumsal uyumuna da katkı sunmaktadır (Wigfield, Gladstone ve Turci, 2016). Buradan hareketle, okuduğunu anlamanın, yalnızca akademik yaşamda kullanılabilecek bir beceri alanı değil, aynı zamanda mesleki veya sosyal yaşantı içinde de geliştirilmesi gereken bir beceri olduğu ifade edilebilir.

Okuma, dünyanın gerçekliklerini anlama, yeni bilgi edinimini kolaylaştırma ve dünyadaki farklı olay ve olgulara karşı eleştirel bir bakış açısı kazanma aracıdır. Bu yönüyle okuma: algılama, yorumlama, analiz ve sentez gibi farklı becerileri içerir (Ehri, 2005). Öznel ve nesnel süreçleri içeren okumanın tam olarak gerçekleştiğinden söz edebilmek için kişinin okuduğunu anlaması gereklidir. Bu durum, üst düzey zihinsel süreçlerin okuma yoluyla işe koşulduğunu belirlemektedir (Coelho ve Correa, 2017).

Diğerleri tarafından yazıya dökülen düşünce ve duygular, kişinin okuduğunu anlama becerisiyle yeniden oluşturulur. Bu bağlamda, kişinin “okuma” faaliyetiyle edindiği bilgilerin bilişsel, duyuşsal ve davranışsal alanda farklılık yaratması söz konusudur. Okunan metnin iletisinin kişide farklılık yaratma süreci, okuduğunu anlama becerisi olarak adlandırılmaktadır (Saracaloğlu ve Karasakaloğlu, 2011). Okumanın gerçek amacı, metindeki iletinin çabuk kavranması ve kişide belirgin bir bilişsel, duyuşsal veya davranışsal farklılık yaratılmasıdır. Kişi okuduğu metinle ne derece fazla etkileşime geçerse, metindeki iletiyi kavrama ihtimali o derece artmaktadir (Davey, 1983).

Metindeki kelimelerin anlamlarının bilinmesi, anlamanın ilk koşuludur. Bununla birlikte cümlelerin ve metnin bütününün anlaşılması daha önemlidir. Metnin bir bütün olarak anlaş1labilmesi, kişinin geçmişte elde ettiği sözcük dağarcığına da bağlıdır. Hazırbulunuşluk olarak da ifade edilen söz konusu birikim, kişinin bilişsel, duyuşsal ve davranışsal erişi düzeyidir (Hock ve Mellard, 2005).

Metindeki iletiyi kendi deneyimleriyle ilişkilendirebilme önemli bir beceridir. $\mathrm{Bu}$ yolla kişi, metni öznel alanına dâhil ederek okuduğu metindeki iletinin çeşitli boyutlarının farkına varabilir. Ancak metindeki iletiyi geçmiş yaşamla ilişkilendirmek bazı durumlarda metindeki iletiye karşı çeşitli önyargıların gelişmesine yol açabilir. Bu durum okunan metnin anlaşılmasını zorlaştırmaktadır (Demir, 2012). Bununla birlikte kişinin okuduğu metni anlaması ve metindeki ana iletiye karşı eleştirel bakış kazanmasının temel koşulu metnin tarafsız olarak değerlendirmesidir. Bu açıdan okunan metnin doğru bir şekilde anlaşılması için 
metne veya iletiye karşı herhangi bir önyargının geliştirilmemiş olması gereklidir (Hegarty ve Golden, 2008).

Okuduğunu anlama, metne ilişkin farklı zihinsel ve duygusal süreçlerin işe koşmasını gerektirir. Bilişsel ve duyuşsal alanda okuduğunu anlama düzeyinin belirlenebilmesi için, okunan metnin temel iletisine yönelik sözlü ya da yazılı soru sorulması yeterlidir. Kişinin yanıtlarının değerlendirilmesi ile okuduğunu anlama düzeyi belirlenebilir. Buna karşın okuduğu metnin kişinin tutum ve davranışlarını nasıl değiştirdiğinin belirlenmesi ise oldukça güçtür (Karatay, 2007; Vega, 1996). Örneğin trafik veya sağlık kurallarını içeren çeşitli uyarı yazılarının kişilerde davranışı nasıl etkilediği veya bu metinlerdeki iletilerin anlaşılıp anlaşılmadığının belirlenmesi için uzun süreli gözlemler yapmak gerekebilir.

Bir metnin yapısını oluşturan etkenlerin (metnin türü ve anlatım biçiminin) bilinmesi, anlamayı kolaylaştırmaktadır (Karatay, 2007). Literatürde metin türleriyle ilgili çeşitli siniflandırmalar bulunsa da genellikle bilgilendirici metinler (deneme, makale vb.) ile öyküleyici metinler (hikâye, roman vb.) olarak ayrıştırılmaktadır (Çeçen, 2011).

Bilgilendirici metinler, kavranması güç olay ve olgular hakkında bilgi vererek okuyucuyu bu yönde aydınlatmak için oluşturulur (Temizkan, 2009). Bu metin türü, bir konunun okuyucu tarafından derinlemesine anlaşılabilmesi için belirli bir olay veya olguyu detaylı bir şekilde açıklama iddiasındadır (Günay, 2007). Bilgi verici metinlerde kurmacaya yer verilmez; bilgiler doğrudan okuyucuya sunulur. $\mathrm{Bu}$ açıdan tarz ve ihtiva açısından öyküleyici metinlerden ayrışmaktadır. Sanatlı anlatım tekniklerinin yer almadığı bu metin türünde dil ve anlatım deseni, iletilmek istenen bilginin düzeyi ve bu bilgiye muhatap olacak kişinin deneyimleri dikkate alınarak oluşturulur (Temizkan, 2009). Bilgilendirici metinler, genellikle terim ve hiyerarşik anafikir dizgesinden oluştuğundan, sözcük dağarcığı zayıf olan kişinin bilgilendirici metinleri anlaması zorlaşabilir (Saenz ve Fuchs, 2005). Bu açıdan bilgilendirici metinlerin anlaşılması, öyküleyici metinlerden daha güçtür (Akyol, 2011; Kurnaz ve Akaydın, 2015).

Bilgi verici bir metnin doğru bir biçimde anlaşılabilmesi için ana ve yardımcı fikirlere ilişkin hiyerarşik yapılanma ve diğer detayların dikkatli belirlenmesi gereklidir. Bu tür metinlerden istifade edebilmek için kişinin metne ilişkin beklentisinin yanında bu tür metinlerin dil ve anlatım özelliklerine de aşina olması önemlidir. Bu noktada okuduğunu anlamanın ön koşulu, metnin türüne ait niteliklerin ve bu türün gerektirdiği okuma biçiminin bilinmesidir (Karatay, 2007). 
Öyküleyici metinler olay akışına dayalıdır ve olaylar belirli bir zaman sürecini kapsar. $\mathrm{Bu}$ metinler, belirli bir başlangıç ile sonuç arasında gelişen kurgusal bir olayı sanatlı anlatımla sunarlar. Öyküleyici metinlerde olay, bakış açısı, anlatıcı, zaman, mekân ve kişiler gibi çeşitli unsurlar söz konusudur (Aktaş, 2000). Bilgilendirici metinlerin aksine öyküleyici metinlerde, okuyucuya verilmek istenen mesaj açık bir şekilde sunulmaz. Okuyucunun mesajı anlaması için bu tür metinler hakkında bilgi sahibi olması, metin içindeki çeşitli ipuçlarını takip etmesi ve çıkarımlar yapması gerekir (Üründü, 2011). Bununla birlikte öyküleyici metinler, bilgilendirici metinlere göre daha kolay anlaşılmaktadır (Akyol, 2011; Üründü, 2011).

Okuduğunu anlamada metin türü belirleyici olsa da metnin güçlük derecesi de önem arz eder. PISA, PIRLS gibi sınavlarda Bloom ya da Haladyna'nın öğrenme taksonomilerine uygun olarak metinlerin güçlük dereceleri bir ölçüt olarak belirlenmekte ve aynı metne ilişkin farklı düzeylerde sorular yer almaktadır. Bu noktada "Bilgiye ulaşma ya da hatırlama" bir düzeyken; "bilgileri bir araya getirme, çıkarım ya da yorumlama" başka bir düzeydir. Ayrıca bu sınavlarda üst düzey bilişsel erişiler için de okuduğunu anlama becerisi ölçülebilmektedir (Birkerts, 2006; Deshpande, 2016). Bir okuduğunu anlama ölçeğinde yer alması gereken ve yukarıda anılan özelliklerin, bu çalışmada da yer almasına gayret edilmiştir. Bu çalışmada okuduğunu anlama düzeyinin belirlenebilmesi için Bloom’un taksonomisi temel alınmış, bu sayede öğretmenlerin bilişsel erişi düzeyleri belirlenmeye çalışılmıştır.

Kişinin okuduğunu anlama düzeyinde okuma hızı ve okuma gücü olarak adlandırılan iki beceri önem taşımaktadır. Okuma hızı, belirli bir sürede bir metni okuyarak anlama çabasıdır. Genel olarak merkezi sistem sınavlarında bu beceri ölçülmeye çalışılmaktadır. Okuma gücü ise belirli bir zaman sınırı olmaksızın okunulan metnin ayrıntılarına erişme durumudur. Özellikle bilgilendirici metinlerde veya metnin tüm ayrıntılarına dikkat edilmesinin önemli olduğu durumlarda okuma gücü etkili olmaktadır. Okuduğunu anlama gücü, temel olarak üç bileşenden oluşur: okunulan metin, okuyucu ve metnin okuyucu tarafindan yorumlanması (Chavez, 2001; Hock ve Mellard, 2005). Bu kapsamda okuduğunu anlama durumunu belirlemeyi amaçlayan çalışmaların sonuçları, ölçümlerde kullanılan metin türlerine, okuyucuların okuma amacına, sözcük bilgisine ve okuyucunun okuduğu metni yorumlamasında kullanılacak ölçüm yöntemlerine bağlı olarak değişecektir (Brantmeier, 2003; Ehri, 2005).

Okuduğunu anlamayı ölçen araştırmaların çoğu okuma hızına odaklanırken (Coiro ve Dobler, 2007; Bell, 2001; Rasinski, 2000; Yamashita, 2008), çeşitli araştırmalar da okuma gücünü ölçmeyi hedeflemektedir (Al-Homoud ve Schmitt, 2009; Willis, 2012; Friedman ve 
Miyake, 2004; Meyer, Brandt ve Bluth, 1980). Okuma hızı, belirli bir zamanda okunan sözcük sayısıdır ve genellikle bir metne ilişkin genel bir görü sağlamak amacıyla kullanılır. Bu açıdan okuma hızını ölçmek ile okuduğunu anlama farklı kavramlardır. Okumayı değerlendirme ve okuduğunu anlamayı değerlendirme birbirinden ayrılır. Örneğin akıcı okuma hızı ölçülür ve akıcı okuma ile okuduğunu anlama arasındaki ilişki değerlendirilir. Kısaca okuma hızı, okuduğunu anlama için bir belirleyici olmamakla birlikte önem arz eden unsurlardandır. Okuma gücü ise bir metni derinlemesine inceleyerek metnin ayrıntılarına erişilmesidir. Okuma gücünün belirlenmesinde birim zamanda okunan kelime sayısından ziyade, kişinin metni kavrama düzeyi önemlidir. Bu doğrultuda öğretmenlerin okuduğunu anlama düzeyinin ölçülmesi amacıyla yürütülen bu çalışmada, öğretmenlerin okuma hızlarından ziyade, okuma güçlerine odaklanılmıştır.

Duygusal ve bilişsel farkındalık ile sözcük dağarcı̆̆ı ve gramer bilgisi okuduğunu anlamayı etkilemektedir. Bununla birlikte hazırbulunuşluk düzeyi, okuduğu metne karşı ilgi ve okuma amacı da okuduğunu anlama düzeyini etkileyebilir. Kişinin okuduğunu anlaması için, metnin dilbilgisi ve anlatım yönünden yeterli olması ile metinde karmaşık mesajların bulunmaması gerekir (Bügel ve Buunk, 1996; Chall, Jacobs ve Baldwin, 2009).

Alanyazında kişinin okuduğunu anlama düzeyi ile sahip olduğu demografik değişkenler arasındaki ilişki, sıklıkla araştırılmıştır. Cinsiyet, yaş, medeni durum, eğitim durumu gibi demografik özelliklerin, okuduğunu anlama üzerinde farklı etkileri olduğunu gösteren çok sayıda araştırma bulunmaktadır (Brantmeier, 2003; Bügel ve Buunk, 1996; Chavez, 2001; Çam 2006; Hsueh-Chao ve Nation, 2000; Karatay, 2007; Phakiti, 2003; Suna 2006; Tayşi 2007). Cinsiyet değişkeniyle ilgili farklı sonuçlar içeren bu araştırmalarda kadınların erkeklere göre çocukluk ve ergenlik dönemlerinde okuduğunu anlama düzeylerinin daha fazla olduğu, ancak zamanla bu farkın erkekler lehine geliştiği belirlenmiştir. Yaş ve mesleki kıdem, okuduğunu anlama üzerinde olumlu etkisi olan bir değişkendir. İnsanlar yaşlandıkça daha fazla deneyim kazanırlar ve yaşam tecrübelerini okudukları metne daha fazla yansıtma eğilimi içinde olurlar (Brantmeier, 2003). Ayrıca kişinin sahip olduğu eğitim seviyesi, okuma ve okuduğunu anlama üzerinde etki etmektedir (Bügel ve Buunk, 1996; Chavez, 2001). Yaygın bilimsel yöntemin izlendiği bu çalışma kapsamında, öğretmenlerin sahip oldukları demografik değişkenlere (cinsiyet, öğrenim durumu ve mesleki kıdem gibi) göre okuduğunu anlama düzeyleri belirlenmeye çalışılacak, elde edilen verilerin alanyazındaki karşılı̆̆ı tartışılacaktır. 
Alanyazında öğrenciler ve öğretmen adayları özelinde yürütülen bazı çalışmalarda okuduğunu anlama düzeyinin oldukça düşük olduğu belirlenmiştir (Kartal ve Özteke, 2010; Topuzkanamış ve Maltepe, 2010). Buna karşın bazı çalışmalarda okuduğunu anlamanın zayıf olduğu saptanmıştır (Başaran, 2013; Yılmaz, Köse ve Korkut, 2009; Ungan, 2008). Ancak literatürde okuduğunu anlamanın farklı düzeylerde olduğunu belirleyen çalışmalar da bulunmaktadır (Odabaş, Odabaş ve Polat, 2008; Can, Türkyılmaz ve Karadeniz, 2010). Öğrencilerin istendik bilgi, beceri ve davranışları kazanmasında öğretmen oldukça kritik bir role sahiptir. Öğrenme durumlarının temel koşullarından olan aktarılabilirlik ilkesi gereği, öğretmenin kendisinin sahip olduğu bilgi, becerileri ve davranışların, öğrencilere daha kolay kazandırıldığı bilinmektedir (Friedman ve Miyake, 2004). Ancak Saracaloğlu ve Karasakaloğlu (2011) ile Topuzkanamış ve Maltepe (2010) yaptıkları araştırmalarda, öğretmen adaylarının okuduğunu anlama düzeylerinin oldukça düşük olduğunu belirlemişlerdir. Bu durum eğitim ve öğretimin kalitesini olumsuz etkileyebilir.

\section{Araştırmanın Amacı ve Önemi}

Okuduğunu anlama, kişinin bilişsel erişi ve sosyal farkındalık düzeyinin göstergesidir. Bilişsel erişi düzeyi, sözel veya yazılı ifadelerle belirlenebilirken sosyal farkındalık, tutum ve davranışlardaki değişim ile belirlenir. Okuduğunu anlama çalışmaları, kişinin bilişsel düzeyinin geliştirilmesine katkı sunabilir. Bu çalışma özelinde temel eğitim (ilkokul ve ortaokul) öğretmenlerinin bilişsel erişi düzeylerinin belirlenmesi hedeflenmemiştir. Ancak öğretmenlerin okuma becerilerine ilişkin nitelikli bilimsel veri elde edilmesi umulmaktadır.

Okuduğunu anlama düzeyi, kişinin sözcük haznesinin yeterliğinden etkilenmektedir. Öğretmenlerinin lisans öğrenimleri boyunca çeşitli okuma kaynaklarına erişim sağladıkları ve çok sayıda farklı sözcük ile karşılaştıkları bilinmektedir. Öğretmenlerin, hizmet öncesi dönemde anadillerini dilbilgisi kurallarına uygun ve akıcı bir şekilde okuyabildikleri de varsayılmaktadır. Bu çalışmanın temel güdü kaynağı, yoğun bir öğrenim sürecinden geçen öğretmenlerin, okudukları metni anlama düzeylerinin üst seviyelerde olması gerektiğine ilişkin beklentidir.

Profesyonel iş yaşamında farklı tür metinlerle karşılaşan öğretmenlerin, bu metinleri anlaması ve doğru bir şekilde yaşamına uyarlaması gereklidir. Öğretmenlerin okuduklarını anlama becerilerinin belirlenmesi, öğretmen yeterliklerinin belirginleşmesini sağlayacaktır. Ayrıca, öğretmenlerin okuduğunu anlama düzeylerine ilişkin akademik verilerin alanyazına sunulması ile öğretmen yetiştirme sisteminin yeterliği ve etkinliğine ilişkin yeni bir tartışma alanı oluşturulacaktır. 
Öğretmenler, öğrencilere anadilin kurallarını ve günlük yaşamda aktif olarak kullanımını öğretmekle birlikte, öğrencilerin okuma alışkanlığı ve okuduğunu anlama becerilerinin geliştirilmesi için çaba sarf etmektedirler. Eğitim sisteminden istifade eden tüm öğrenciler, temel okuma ve yazma becerilerini sınıf öğretmenlerinden kazanmakla birlikte, sistem içindeki tüm öğretmenlerin dil becerilerinden de aktif bir şekilde etkilenmektedirler. Öğrencilere okuma becerilerini kazandıran öğretmenlerin yeterliklerinin belirlenmesi, eğitim sisteminin kalitesinin tespit edilmesi açısından önemlidir. Öğretmenlerin okuma becerilerinin belirlenmesi ile yalnızca öğrencilere yönelik eğitimin kalitesi değil, aynı zamanda öğretmenlerin yazılı metinlerde anlatılmak istenen iletileri kavrama düzeyleri de belirginleșecektir. Ayrıca alanyazındaki araştırmalarda okuduğunu anlama becerisinin, çalışanların iletişim becerilerini (Bügel ve Buunk, 1996), verimliliğini (Ehri, 2005) ve örgüt içindeki etkinliğini arttırdığı, yeni iş olanaklarına imkân sağladığına (Chavez, 2001) yönelik bulgulara da rastlanmaktadır.

Alanyazında eğitim sistemi içinde aktif olarak çalışan öğretmenlerin okuduğunu anlama düzeylerine ilişkin bir araştırmayla henüz karşılamamış olması bu araştırmanın yürütülmesindeki gerekçelerden biridir. $\mathrm{Bu}$ araştırma ile alanyazında eksikliği hissedilen öğretmenlerinin okuduğunu anlama durumları belirlenecek ve önemli bir boşluk kapatılacaktır. Ayrıca politika belirleyicilere, öğretmenlere ve öğretmen yetiştiren kurumlara yönelik öneriler geliştirilmeye çalışılacaktır. Türk eğitim bilimleri alanyazınındaki bilinen ilk araştırma olması ve bilime katkı sağlayacak verileri üretmesi açısından bu araştırma ayrıca önem taşımaktadır.

$\mathrm{Bu}$ çalışmanın amacı, temel eğitim öğretmenlerinin okuduğunu anlama düzeylerinin belirlenmesidir. Araştırma kapsamında aşağıdaki sorulara yanıt aranacaktır:

1. Temel eğitim öğretmenlerinin okuduğunu anlama düzeyleri nedir?

2. Temel eğitim öğretmenlerinin okuduğunu anlama düzeyleri ile demografik özellikleri (cinsiyet, eğitim durumu, branş ve mesleki kıdem) arasında anlamlı bir farklılık var midır?

\section{Yöntem}

2016 yılında başlayıp 2019 yılında tamamlanarak uzun bir sürece yayılan bu çalışmada, öğretmenlerin okuduklarını anlama düzeylerinin belirlenebilmesi için nicel araştırma yöntemleri arasında yer alan betimsel tarama modeli ile kullanılmıştır. Betimsel tarama modelinde araştırma problemi, kendi bağlamı içinde belirlenmeye çalışılmaktadır. Betimsel 
tarama modeli, bir olgunun geçmiş ve günümüzdeki etkileşimlerini var olduğu biçimiyle tasavvur etmeyi hedefleyen araştırma yaklaşımıdır (Büyüköztürk, 2017). Betimsel tarama çalışmalarında var olan durumda herhangi bir değişiklik veya farklı değişkenler arası etkileşimleri inceleme çabası gösterilmez.

\section{Çalışma Grubu}

Örneklem 1: Bu araştırmada geliştirilen ‘Okuduğunu Anlamayı Değerlendirme Ölçeği'nin ana uygulama için kullanılabilir olduğunu belirlemek üzere bir ön uygulama grubu oluşturulmuştur. Ölçeğin ön uygulaması araştırma örnekleminde yer almayan, basit tesadüfi örnekleme yöntemi ile belirlenen ve MEB'in Ankara, Mersin, Yalova ve Antalya'da düzenlediği hizmet içi eğitim faaliyetlerine 2016 yılı Şubat ayında katılan öğretmenler üzerinde yürütülmüştür. Ön uygulama grubu, Kütahya, Uşak, Afyonkarahisar, Burdur, Isparta, Antalya, Muğla, Manisa, Aydın, Denizli ve İzmir İllerinde görev yapan, örneklemle benzerlik gösteren ve ana uygulamaya katılmayan 149 öğretmenden oluşmaktadır. Ön uygulama grubundaki öğretmenlerle yüz yüze görüşülerek ölçekleri doldurmaları istenmiş ve doldurulan ölçekler araştırmacı tarafından toplanmıştır. Ön uygulama çalışmaları, 2016 yılı şubat ayında başlamış ve aynı yıl ekim ayında tamamlanmıştır.

Örneklem 2: Araştırmanın çalışma evreni, Ankara ilinin 25 ilçesinde 2016 - 2019 yılları arasında görev yapmakta olan 12272 öğretmenden oluşturmaktadır (ilkokul ve ortaokulda görev yapan öğretmenler). Örneklemde bulunan öğretmenlerin belirlenmesinde olasılığa dayalı örnekleme biçimlerinden biri olan tabakalı örnekleme tekniği kullanılmıştır (Büyüköztürk, 2017). Bu doğrultuda örneklem sayısı 384 öğretmen olarak seçilmiştir. Ancak araştırmanın geçerliğini artırmak için ulaşılabilecek maksimum örnek sayısı hedeflenmiş, örneklemdeki okullarda çalışılan tüm öğretmenlere ulaşılmaya çalışılmıştır. Bu bağlamda örneklemde bulunan öğretmenlere (bu noktadan sonra katılımcı olarak anılacaklardır), 2500 ölçek gönderilmiş, 1913 ölçek toplanabilmiştir. Bu ölçeklerden 377'si eksik ya da hatalı doldurma, 121'i de uç değerlere sahip olduğu için analize tabi tutulmamıştır. Hesaplanan örneklem büyüklüğünü karşılayan 1415 ölçek analize dâhil edilmiştir. Araştırmaya katılan katılımcılara ilişsin demografik bilgiler Tablo 1'de görülmektedir.

Tablo 1 incelendiğinde katılımcıların \%61,20’si kadın olduğu, \%64,52'sinin lisans düzeyinde eğitim aldıkları, \%40,78'inin mesleki kıdeminin 11 yıl ve üzerinde olduğu ve \%14,06’sının sınıf öğretmeni olduğu belirlenmiştir. 
Tablo 1. Katılımcıların demografik bilgileri

\begin{tabular}{|c|c|c|c|c|}
\hline Değişkenler & Alt Kategoriler & $\mathrm{N}$ & $\%$ & Toplam \\
\hline \multirow{2}{*}{ Cinsiyet } & Erkek & 549 & 38,80 & \multirow{2}{*}{1415} \\
\hline & Kadın & 866 & 61,20 & \\
\hline \multirow{2}{*}{ Eğitim Durumu } & Lisans & 913 & 64,52 & \multirow{2}{*}{1415} \\
\hline & Lisansüstü & 502 & 35,48 & \\
\hline \multirow{3}{*}{ Mesleki Kıdem } & 5 yıl ve altı & 377 & 26,64 & \multirow{3}{*}{1415} \\
\hline & $6-10$ y1l & 461 & 32,58 & \\
\hline & 11 yıl ve üstü & 577 & 40,78 & \\
\hline \multirow{14}{*}{ Branş } & Beden Eğitimi & 63 & 4,45 & \multirow{14}{*}{1415} \\
\hline & Bilişim Teknolojileri & 42 & 2,97 & \\
\hline & Din Kültürü ve Ahlak Bilgisi & 104 & 7,35 & \\
\hline & Fen ve Teknoloji & 122 & 8,62 & \\
\hline & Görsel Sanatlar & 46 & 3,25 & \\
\hline & Matematik & 133 & 9,40 & \\
\hline & Müzik & 45 & 3,18 & \\
\hline & Okul Öncesi & 136 & 9,61 & \\
\hline & Rehberlik ve Psikolojik Danışma & 59 & 4,17 & \\
\hline & Sinif & 199 & 14,06 & \\
\hline & Sosyal Bilgiler & 117 & 8,27 & \\
\hline & Teknoloji ve Tasarım & 79 & 5,58 & \\
\hline & Türkçe & 141 & 9,96 & \\
\hline & Yabancı Dil & 129 & 9,12 & \\
\hline
\end{tabular}

\section{Ölçme Aracının Geliştirilmesi}

Araştırmada kullanılan 'Okuduğunu Anlamayı Değerlendirme Ölçeği', alanyazında kullanılan ölçek ve uygulamalar (Al-Homoud ve Schmitt, 2009; Baltacı, 2017; Karatay, 2007; Keenan, Betjemann ve Olson, 2008; Phakiti, 2003; Yamashita, 2008) incelenerek araştırmac1 tarafından geliştirilmiştir. Araştırma kapsamında katılımcıların okuduğunu anlama düzeylerini belirleyebilmek için, çeşitli metinlerden oluşan bir ölçek geliştirilmesine karar verilmiştir. Ölçeğin bilgilendirici ve öyküleyici metinlerden oluşmasının katılımcıların 
okuduğunu anlama düzeylerinin belirlenmesi için yeterli olabileceği öngörülmüştür. Böylece ölçek bilgilendirici ve öyküleyici metinleri içerecek şekilde tasarlanan iki ayrı ölçme formundan ve katılımcıların demografik özelliklerini belirlemeye yönelik kişisel bilgiler formundan oluşmaktadır.

$\mathrm{Bu}$ çalışmada kullanılması planlanan ölçeğin geliştirme çalışmaları üç aşamada gerçekleştirilmiştir. Öncelikle alanyazında bulunan ve yukarıda anılan ölçeklerden yararlanılarak 30 metin (15 bilgilendirici ve 15 öyküleyici) seçilmiştir. Her metin için Bloom'un yenilenmiş taksonomisine uygun olarak hazırlanmış 6 sorudan oluşan bir soru havuzu oluşturulmuştur. Soru havuzundaki metinlerin güçlük dereceleri bir ölçütken; aynı metne ilişkin farklı düzeylerde soruların yer alması da diğer bir ölçüt olarak belirlenmiştir.

Bloom taksonomisi dikkate alınarak soru havuzundaki metinler farklı güçlük seviyelerine göre sınıflandırılmıştır. Buna göre her kategori (hatırlama, anlama, uygulama, çözümleme, değerlendirme, yaratma) beş metni kapsayacak şekilde gruplanmıştır. Ardından metin içinde yer alan sorular benzer bir sınıflama işlemiyle sıralanmıştır. Böylece her bir sorunun bir kategoriyi ölçebilecek düzeyde olması sağlanmıştır. 30 metin ve 180 soru olarak hazırlanan taslak ölçek formu, doktora düzeyinde eğitim almış 25 kişilik bir uzman görüşüne sunulmuştur. Uzman görüşleri doğrultusunda taslak ölçekten 6 metin çıkarılmıştır. Bu sayede ön uygulamaya hazır hale getirilen ölçek, her bir öğrenme kategorisi için 4 metin ve 6 soruyu içermekte ve toplamda 24 metin ve 144 sorudan oluşmaktadır. Ölçeğin her iki bölümü (bilgilendirici ve öyküleyici) 12 metin ve 72 soruyu içermektedir.

Ölçekte açık uçlu sorulara yer verilmemiştir. Her metnin altında katılımcı görüşlerinin alınması amacıyla yeterli boşluk bırakılmıştır. Bunun yanında her metinde yer alan kritik veya bilinmeyen kelimeler için bir sözlük bölümü oluşturulmuştur. Ölçeğin ön uygulama için hazırlanan taslak sürümü, 149 öğretmenden oluşan (örneklem 1) bir gruba uygulanmıştır.

Ön uygulama verilerinin değerlendirilmesinde Shanker ve Ekwall (2009) tarafından geliştirilen 'Yanlış Analiz Değerlendirme Anahtarı' kullanılmıştır. Bu aşamada katılımcıların doğru olarak cevapları ' 1 ', yanlış cevapları ' 0 ' olarak puanlanmıștır. Böylelikle her bir metin türüne (bilgilendirici ve öyküleyici) ilişkin ölçme aracından alınabilecek en yüksek puan 72 iken en düşük puan 0 olarak belirlenmiştir. Ölçek puanlarının yorumlanması için ortalama puan değerleri beş kategoriye ayrılmıştır. Puan ortalaması 0 - 14,3 değerleri arasında olanlar 'çok zayıf' olarak belirlenmiştir. , 14,4 - 28,8 arasında olanlar 'zayıf', 28,9 - 43,3 arası 'orta', 43,4-57,8 arası 'iyi’ ve 57,9- 72 arası ‘çok iyi' olarak belirlenmiştir. 
Ön uygulama ölçeğini oluşturan her madde, uzmanlar tarafından bağımsız olarak değerlendirilmiştir. Değerlendirmenin güvenirliği, tesadüfi hata kaynağı olarak puanlayıcılardan etkilenmektedir. Tesadüfi hataları en aza indirmek ve ölçme aracına ait puanlama anahtarının güvenilirliğini tespit etmek için Krippendorff'un alfa $(\alpha)$ katsayısı, Cohen'in kappa $(\kappa)$ katsayısı ve Pearson katsayısı birlikte kullanılmıştır.

Kappa $(\kappa)$ katsayısı, sınıflama düzeyinde puanlama yapan en az iki puanlayıcının uyum seviyesine odaklanır (Cohen, 1968). $\kappa$ Katsayısı -1 ile +1 arasında değer almaktadır. $\kappa$ 'nın pozitif değeri, puanlayıcıların birbirine uyum derecesinin şans sonucu oluşabilecek uyumdan fazla olacağını gösterir. $\kappa$ 'nın negatif değeri ise puanlayıcıların uyumunun tesadüfi beklentilerden daha az olacağını belirler (Fleiss, 1971). Ön uygulama verileri için bu katsayının pozitif ve yüksek düzeyde olduğu belirlenmiştir $(\kappa=.711 ; \mathrm{p}<.01) . \mathrm{Bu}$ değer, puanlayıcılar arasında önemli düzeyde bir uyum olduğunu göstermektedir (Landis ve Koch, 1977).

Krippendorff Alfa $(\alpha)$ katsayısı, tesadüfi düzeltme olmaksızın puanlayıcılar arası konsesusu hesaplamaktadır. Krippendorff $(\alpha)$ katsayısının yorumlanmasında $\alpha=1$ olması puanlayıcılar arasındaki uyumun mükemmel olduğunu, $\alpha=0$ ise tam uyumsuzluğu belirler (Krippendorff , 1995). Ön uygulama sonucunda $(\alpha)$ katsayısı .715 olarak belirlenmiştir. Alfa katsayısının bu değeri, ölçeğin önemli ölçüde uyumlu ve güvenilir olduğunu göstermektedir.

Ön uygulamada Pearson momentler çarpımı incelenmiş ve her iki puanlayıcı arasında $(\mathrm{r}=.907, \mathrm{p}<0,01)$ anlamlı, pozitif ve yüksek bir ilişki belirlenmiştir. Korelasyon katsayısı -1,00 ile $+1,00$ arasında değişmekte ve katsayının mutlak değeri büyüdükçe iki değer arasındaki ilişkinin derecesi de artmaktadır. Büyüköztürk (2017) korelasyon katsayısının (r) 0.80 ile 1.00 arasında olmasının, her iki değişken arasında yüksek düzeyde bir ilişki olduğunun kanıtı olduğunu bildirmektedir. Puanlayıcılara ilişkin güvenirlik bulgularından hareketle ölçme aracının ve değerlendirme anahtarının yeterli düzeyde güvenilir olduğu belirlenmiştir.

Ön uygulama verilerini değerlendiren her iki puanlayıcının ölçümleri, yukarıdaki güvenirlik analizine ek olarak ayrı bir işleme tabi tutulmuştur. Ölçeğin güvenirliği KuderRichardson 20 (KR-20) güvenirlik katsayısıyla belirlenmiştir. Çok boyutlu veya birden fazla ölçme aracını barındıran ölçeklerin güvenirlik sınamalarında KR-20 katsayısı daha dengeli bir güvenirlik değeri sağlayabilir (Raykov, 1997). Bu düşünceden hareketle, her bir ölçek için KR-20 değerlerinin belirlenmesine karar verilmiştir. Öyküleyici metinlerin yer aldığı bölüme ilişkin KR-20 değeri .59 ve bilgilendirici metinlerin yer aldığı bölüm için bu değer, 63 olarak hesaplanmıştır. Ölçeğin her iki formu da kabul edilebilir sınırların altındadır (Bland ve 
Altman, 1977). Güvenirliği arttırabilmek için 6 metnin ölçekten çıkarılmasına karar verilmiştir. Çıkarılan metinlerden sonra güvenirlik analizi yeniden yapılmış ve öyküleyici metinlerin yer aldığı bölüme ilişkin KR-20 değeri .74 olarak hesaplanmıştır. Bu değer, bilgilendirici metinlerin yer aldığı bölüm için .82 'dir. Ölçeğin genel güvenirlik katsayısı ise .81 olarak belirlenmiştir.

Geçerlik ve güvenirlik analizi sonucu uygulamaya hazır hale getirilen ölçek 18 metin ve 108 sorudan oluşmaktadır. Ölçeğin son hali uzman görüşüne sunularak "okunabilirlik" analizi yapılmıştır. Uzman görüşleri neticesinde metinler yeniden düzenlenmiş ve ana uygulamaya hazır hale getirilmiştir. Her iki metin türüne (bilgilendirici, öyküleyici) ait ölçme aracından alınabilecek en yüksek puan 54 iken en düşük puan 0 olarak belirlenmiştir. Ölçekten alınan puanların yorumlanmasında beş kategori kullanılmıştır. Buna göre, ortalama puan değerleri: 0 - 10.80 arası 'çok zayıf', 10.81 - 21.70 arası 'zayıf', 21.71 - 32.50 arası 'orta', $32.51-43.30$ arası 'iyi' ve 43.31 - 54 arası 'çok iyi’ olarak belirlenmiştir.

Ölçekte yer alan tüm metinler ile metne ilişkin sorular aynı sayfada yer almakta ve her bir metnin altında metinde geçen kritik sözcüklerin anlamlarının yer aldığı sözlük bölümü bulunmaktadır. Ek olarak okuduğunu anlama ölçeğinin giriş bölümünde katılımcıların demografik özelliklerinin belirlenebilmesi amacıyla bir kişisel bilgi formu yer almaktadır.

'Okuduğunu Anlamayı Değerlendirme Ölçeği', katılımcıların belirli bir süre içinde okudukları metnin ne kadarını anladıklarını ölçen hız ölçümlerinden ziyade, kendi belirledikleri bir süre içinde okudukları metinden en çok anlamı yakalamalarını hedefleyen güç ölçümüne yöneliktir. Bu açıdan araştırmanın veri toplama süreci örneklem büyüklüğü de dikkate alınarak geniş bir zamana yayılmıştır. 2017 yılı ocak ayında başlayan veri toplama işlemleri, 2019 yılı kasım ayında tamamlanmıştır. Ölçekler, Ankara ili ilçelerinde görev yapan öğretmenlere araştırmacı tarafından ulaştırılmıştır. Ölçeğin kapsam geçerliğini arttırabilmek ve katılımcıları motive edebilmek için, katılımcıların okudukları metne odaklanmaları istenmiştir. Ayrıca katılımcılardan toplanan verilerin bilimsel bir araştırmanın parçası olacağı ve kişisel bilgilerinin kullanılmayacağı belirtilmiştir. Katılımcılardan soruları kendi anlayabilecekleri hızlarda, kendi belirledikleri ortamda dikkatlice okumaları ve kendilerine göre en doğru olan seçeneği işaretlemeleri istenmiştir. Bu nedenle ölçeğin doldurma süresi kişiden kişiye değişmektedir. 


\section{Verilerin Analizi}

Ölçekten elde edilen veriler, aykırı değerler ve hatalı doldurmalar ayıklandıktan sonra analiz sürecine dâhil edilmiştir. Araştırmada katılımcıların okuduklarını anlama düzeylerinin belirlenmesi amacıyla toplanan verilerin analizinde betimsel istatistikler kullanılmıştır. Öğretmenlerin okuduklarını anlama düzeylerinin cinsiyet, eğitim durumu, branş ve mesleki kıdeme göre anlamlı bir şekilde farklılaşıp farklılaşmadığını belirlemek için t-testi ve tek yönlü varyans analizi (ANOVA) kullanılmıştır. Bilgilendirici ve öyküleyici metinleri anlama düzeyi arasındaki ilişki ise korelasyon analizi ile hesaplanmıştır. Manidarlık sınamaları $\mathrm{p}<.05$ düzeyinde yapılmıştır. Tüm analizler istatistik sosyal bilimler için istatistik programında (SPSS) yapılmış; KR-20, Kappa ve Krippendorff katsayısıları için ayrı bir hesaplama programı kullanılmıştır.

\section{Bulgular}

Araştırma kapsamında toplanan verilere ilişkin çözümlemeler, bu bölümde yer almaktadır. Katılımcıların okuduğunu anlama düzeylerine ilişkin bulgular Tablo 2'de görülmektedir.

Tablo 2. Katılımcıların okuduğunu anlama düzeylerine ilişkin betimsel istatistikler

\begin{tabular}{llcccccc}
\hline \multicolumn{1}{c}{ Boyutlar } & $\mathrm{N}$ & $\overline{\mathrm{X}}$ & $\mathrm{sd}$ & 1 & 2 & 3 \\
\hline 1. Öyküleyici Metinleri Anlama Düzeyi & 1415 & 32.61 & 10.76 & - & & \\
2. Bilgilendirici Metinleri Anlama & 1415 & 16.37 & 11.82 & $.86^{*}$ & - & \\
$\begin{array}{l}\text { Düzeyi } \\
\text { 3. Genel Okuduğunu Anlama Düzeyi }\end{array}$ & 1415 & 24.49 & 11.28 & $.66^{*}$ & $.83^{*}$ & -
\end{tabular}

* Spearman rho $\mathrm{p}<0.05$

Tablo 2 incelendiğinde katılımcıların öyküleyici metinleri iyi düzeyde anladıkları $(\overline{\mathrm{X}}=32.61)$; bilgilendirici metinleri zayıf düzeyde $(\overline{\mathrm{X}}=16.37)$ ve genel olarak okuduklarını orta düzeyde $(\bar{X}=24.49)$, anladıkları belirlenmiştir. Bilgilendirici metinleri anlama düzeyi ile öyküleyici metinleri anlama düzeyi arasında pozitif yönlü, yüksek düzeyli bir ilişki bulunmaktadır $(\mathrm{r}=.86)$. Genel okuduğunu anlama düzeyi ile öyküleyici metinleri anlama düzeyi arasında pozitif yönlü orta düzeyli $(\mathrm{r}=.66)$ ve bilgilendirici metinleri anlama düzeyi arasında pozitif yönlü yüksek düzeyli $(\mathrm{r}=.83)$ bir ilişki belirlenmiştir. Tablo 3'de katılımcıların okuduğunu anlama düzeylerinin cinsiyete göre değişimi yer almaktadır. 
Tablo 3. Katılımcıların okuduğunu anlama düzeylerinin cinsiyet değişkenine göre farklılaşması - bă̆ımsız örneklem t-testi analiz sonuçları

\begin{tabular}{|c|c|c|c|c|c|c|c|}
\hline Boyutlar & Cinsiyet & $\mathrm{N}$ & $\bar{X}$ & SS & $\mathrm{sd}$ & $\mathrm{t}$ & $\mathrm{p}$ \\
\hline Öyküleyici Metinleri Anlama & Erkek & 549 & 34.50 & 10.40 & \multirow{2}{*}{1413} & \multirow{2}{*}{6.38} & \multirow{2}{*}{$.001 *$} \\
\hline Düzeyi & Kadın & 866 & 30.72 & 11.13 & & & \\
\hline Bilgilendirici Metinleri Anlama & Erkek & 549 & 18.36 & 11.94 & \multirow[t]{2}{*}{1413} & \multirow{2}{*}{6.16} & \multirow{2}{*}{$.001 *$} \\
\hline Düzeyi & Kadın & 866 & 14.39 & 11.71 & & & \\
\hline Genel Okuduğunu Anlama Düzeyi & $\begin{array}{l}\text { Erkek } \\
\text { Kadın }\end{array}$ & $\begin{array}{l}549 \\
866\end{array}$ & $\begin{array}{c}26.44 \\
22.56\end{array}$ & $\begin{array}{l}11.15 \\
11.42\end{array}$ & 1413 & 6.25 & $.001 *$ \\
\hline
\end{tabular}

$(*) \mathrm{p}<.05$

Tablo 3 incelendiğinde, katılımcıların öyküleyici metinleri anlama düzeyleri, cinsiyete göre anlamlı bir şekilde değişmektedir $\left[\mathrm{t}_{(1413)}=6.38 ; \mathrm{p}<.05\right]$. Erkek katılımcılar $(\overline{\mathrm{X}}=34.50)$, kadınlara göre ( $\overline{\mathrm{X}}=30.72)$ öyküleyici metinleri daha fazla anlamaktadır. Öyküleyici metinleri erkekler 'iyi' düzeyde anlarken, kadınlar 'orta' düzeyde anlamaktadırlar. Benzer şekilde bilgilendirici metinleri anlama düzeyleri de cinsiyetle anlamlı şekilde farklılaşmaktadır $\left[\mathrm{t}_{(1413)}=6.16 ; \mathrm{p}<.05\right]$. Erkekler $(\overline{\mathrm{X}}=18.36)$, kadınlara göre $(\overline{\mathrm{X}}=14.39)$ bilgilendirici metinleri daha fazla anlamaktadırlar. Bununla birlikte bilgilendirici metinleri hem erkekler hem de kadınların 'zayıf' düzeyde anladıkları belirlenmiştir. Genel olarak okuduğunu anlama düzeyi, cinsiyete göre anlamlı bir şekilde farklılaşmaktadır $\left[\mathrm{t}_{(1413)}=6.25 ; \mathrm{p}<.05\right]$. Erkekler $(\bar{X}=26.44)$, kadınlara göre $(\bar{X}=22.56)$ daha fazla oranda okuduğunu anlamaktadır. Ayrıca, okuduğunu anlama düzeyi hem erkekler hem de kadınlar için de 'orta' düzey olarak belirlenmiştir. Katılımcıların öğrenim durumları ile okuduğunu anlama düzeylerine ilişkin analiz sonuçları Tablo 4'de görülmektedir.

Tablo 4. Katılımcıların okuduğunu anlama düzeylerinin eğitim durumu değişkenine göre farklılaşması - bağımsız örneklem t-testi analiz sonuçları

\begin{tabular}{|c|c|c|c|c|c|c|c|}
\hline Boyutlar & Eğitim & $\mathrm{N}$ & $\overline{\mathrm{X}}$ & SS & sd & $\mathrm{t}$ & $\mathrm{p}$ \\
\hline Öyküleyici Metinleri Anlama & Lisans & 913 & 27.14 & 10.05 & \multirow{2}{*}{1413} & \multirow{2}{*}{18.6} & \multirow{2}{*}{$.001^{*}$} \\
\hline Düzeyi & Lisansüstü & 502 & 38.09 & 11.48 & & & \\
\hline Bilgilendirici Metinleri Anlama & Lisans & 913 & 15.49 & 10.53 & \multirow[t]{2}{*}{1413} & \multirow{2}{*}{2.72} & \multirow{2}{*}{$.006^{*}$} \\
\hline Düzeyi & Lisansüstü & 502 & 17.24 & 13.10 & & & \\
\hline Genel Okuduğunu Anlama & Lisan & 913 & 21.31 & 10.30 & \multirow[t]{2}{*}{1413} & \multirow{2}{*}{10.3} & \multirow[t]{2}{*}{$.001 *$} \\
\hline Düzeyi & Lisansustu & 502 & 27.68 & 12.29 & & & \\
\hline
\end{tabular}

$(*) \mathrm{p}<.05$ 
Tablo 4'e göre katılımcıların öğrenim düzeyleri, öyküleyici metinleri anlama düzeyleri $\left[\mathrm{t}_{(1413)}=18.6 ; \mathrm{p}<.05\right]$ ve bilgilendirici metinleri anlama düzeyleri $\left[\mathrm{t}_{(1413)}=2.72 ; \mathrm{p}<.05\right]$ anlaml bir şekilde farklılaşmaktadır. Öyküleyici metinleri, lisansüstü eğitime sahip olan katılımcılar $(\overline{\mathrm{X}}=38.09)$, lisans $(\overline{\mathrm{X}}=27.14)$ mezunu meslektaşlarına göre daha fazla anlamaktadırlar. Lisansüstü eğitim seviyesine sahip olan katılımcıların öyküleyici metinleri ‘iyi’ düzeyde, lisans mezunu katılımcıların ise aynı metinleri 'orta' düzeyde anladıkları belirlenmiştir. Benzer şekilde lisansüstü mezunu katılımcılar $(\overline{\mathrm{X}}=17.24)$, lisans $(\overline{\mathrm{X}}=15.49)$ mezunu meslektaşlarına göre bilgilendirici metinleri daha fazla anlamaktadırlar. Bilgilendirici metinleri anlama düzeyinin, hem lisans hem de lisansüstü eğitim durumunda 'zayıf' düzeyde olduğu belirlenmiştir. Genel olarak öğrenim durumu ile okuduğunu anlama düzeyi arasında anlamlı bir farkl1lık bulunmaktadır $\left[\mathrm{t}_{(1413)}=10.3 ; \mathrm{p}<.05\right]$. Lisansüstü mezunu olanlar okuduklarını 'orta' düzeyde ( $\overline{\mathrm{X}}=27.68)$ anlarken, lisans $(\overline{\mathrm{X}}=21.31)$ mezunları okuduklarını 'zayıf' düzeyde anlamaktadırlar. Tablo 5'te katılımcıların mesleki kıdemleri ile okuduğunu anlama düzeylerine ilişkin analiz sonuçları yer almaktadır.

Tablo 5. Katılımcıların okuduğunu anlama düzeylerinin mesleki kıdem değişkenine göre farklılaşması - tek yönlü varyans analizi (ANOVA) sonuçları

\begin{tabular}{|c|c|c|c|c|c|c|c|c|}
\hline Boyutlar & Mesleki Kıdem & $\mathrm{N}$ & $\overline{\mathrm{X}}$ & Ss & $\mathrm{Sd}$ & $\mathrm{F}$ & $\mathrm{p}$ & Fark \\
\hline $\begin{array}{l}\text { Öyküleyici } \\
\text { Metinleri Anlama } \\
\text { Düzeyi }\end{array}$ & $\begin{array}{l}\text { (1) } 5 \text { y1ldan az } \\
\text { (2) } 6-10 \text { y1l } \\
\text { (3) } 11 \text { y1l ve } \\
\text { üzeri }\end{array}$ & $\begin{array}{l}377 \\
461 \\
577\end{array}$ & $\begin{array}{l}27.31 \\
32.00 \\
38.51\end{array}$ & $\begin{array}{l}9.10 \\
12.57 \\
10.59\end{array}$ & $\begin{array}{c}2 ; \\
1412\end{array}$ & 3.87 & .021 & $\begin{array}{l}1-2 \\
1-3 \\
2-3\end{array}$ \\
\hline $\begin{array}{l}\text { Bilgilendirici } \\
\text { Metinleri Anlama } \\
\text { Düzeyi }\end{array}$ & $\begin{array}{l}\text { (1) } 5 \text { yildan az } \\
\text { (2) } 6-10 \text { y1l } \\
\text { (3) } 11 \text { y1l ve } \\
\text { üzeri }\end{array}$ & $\begin{array}{l}377 \\
461 \\
577\end{array}$ & $\begin{array}{l}14.60 \\
16.12 \\
18.42\end{array}$ & $\begin{array}{c}11.11 \\
12.6 \\
11.98\end{array}$ & $\begin{array}{c}2 ; \\
1412\end{array}$ & 4.35 & .013 & $\begin{array}{l}1-2 \\
1-3 \\
2-3\end{array}$ \\
\hline $\begin{array}{l}\text { Genel } \\
\text { Okuduğunu } \\
\text { Anlama Düzeyi }\end{array}$ & $\begin{array}{l}\text { (1) } 5 \text { y1ldan az } \\
\text { (2) } 6-10 \text { y1l } \\
\text { (3) } 11 \text { y1l ve } \\
\text { üzeri }\end{array}$ & $\begin{array}{l}461 \\
577\end{array}$ & $\begin{array}{l}20.96 \\
24.07 \\
28.47\end{array}$ & $\begin{array}{l}10.11 \\
12.48 \\
11.28\end{array}$ & $\begin{array}{c}2 ; \\
1412\end{array}$ & 4.14 & .016 & $\begin{array}{l}1-2 \\
1-3 \\
2-3\end{array}$ \\
\hline
\end{tabular}

Tablo 5'ye göre katılımcıların öyküleyici metinleri anlama düzeyleri mesleki kıdeme göre anlamlı bir şekilde değişmektedir $\left[\mathrm{F}_{(2 ; 1412)}=3.87 ; \mathrm{p}<.05\right] .11$ y1l üzeri kıdeme sahip olan katılımcılar $(\overline{\mathrm{X}}=38.51), 5$ yıl ve altında $(\overline{\mathrm{X}}=27.31)$ ve 6-10 yıl arası mesleki k1deme sahip olanlara $(\overline{\mathrm{X}}=32.00)$ göre öyküleyici metinleri daha çok anlamaktadırlar. Bununla birlikte 
mesleki kıdemleri 11 yıl ve daha fazla olan katılımcıların öyküleyici metinleri ‘iyi’ düzeyde anladığı, buna karşın mesleki kıdemi 10 yıl ve daha az olan katılımcıların aynı metinleri 'orta' düzeyde anladığı belirlenmiştir. Katılımcıların bilgilendirici metinleri anlama düzeyleri, mesleki k1deme göre anlamlı bir farkl1l1k göstermektedir $\left[\mathrm{F}_{(2 ; 1412)}=4.35 ; \mathrm{p}<.05\right] .11$ y1l ve üzeri kıdeme sahip olanlar ( $\overline{\mathrm{X}}=18.42), 5$ y1l ve alt1 $(\overline{\mathrm{X}}=14.60)$ ile 6-10 y1l mesleki k1deme sahip olanlara $(\overline{\mathrm{X}}=16.12)$ göre bilgilendirici metinleri daha çok anlamaktadırlar. Katılımcıların bilgilendirici metinleri anlama düzeyinin, mesleki kıdemin tüm alt kategorilerinde 'zayıf' düzeyde gerçekleşmiştir. Genel olarak okuduğunu anlama düzeyi ise mesleki kıdemle anlamlı olarak değişmektedir $\left[\mathrm{F}_{(2 ; 1412)}=4.14 ; \mathrm{p}<.05\right]$. Okuduğunu anlama düzeyi 11 yıl ve daha çok kıdeme sahip olanlar $(\overline{\mathrm{X}}=28.47)$ ile 6-10 yıl kıdeme sahip olanlarda $(\bar{X}=24.07)$ 'orta' seviyede gerçekleşirken; 5 yıl ve altı mesleki kıdeme sahip olanlarda 'zayıf' düzeyde olduğu belirlenmiştir ( $\bar{X}=20.96)$. Tablo 6'te katılımcıların branşlarına göre okuduğunu anlama düzeylerinin değişimine ilişkin analiz sonuçları yer almaktadır.

Tablo 6. Katılımcıların okuduğunu anlama düzeylerinin branş değişkenine göre farklılaşması - tek yönlü varyans analizi (ANOVA) sonuçları

\begin{tabular}{|c|c|c|c|c|c|c|c|c|}
\hline Boyutlar & Branş & $\mathrm{N}$ & $\bar{X}$ & Ss & $\mathrm{Sd}$ & $\mathrm{F}$ & $\mathrm{p}$ & Fark \\
\hline \multirow{14}{*}{ 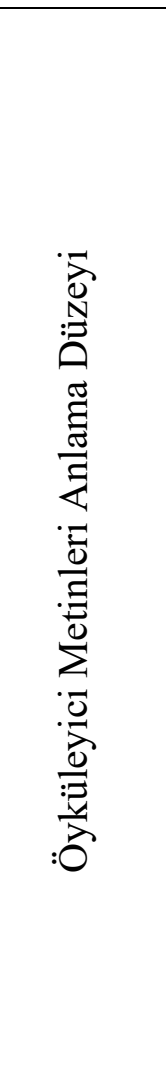 } & 1. Beden Eğitimi & 63 & 21.65 & 13.69 & \multirow{14}{*}{$\begin{array}{c}12 \\
1402\end{array}$} & \multirow{14}{*}{4.21} & \multirow{14}{*}{.015} & \multirow{14}{*}{$\begin{array}{c}13-1 \\
13-5 \\
13-7 \\
13-12\end{array}$} \\
\hline & 2. Bilişim Tek. & 42 & 30.19 & 9.97 & & & & \\
\hline & 3. DKAB & 104 & 39.77 & 8.96 & & & & \\
\hline & 4. Fen/Teknoloji & 122 & 29.08 & 10.42 & & & & \\
\hline & 5. Görsel San. & 46 & 23.64 & 14.69 & & & & \\
\hline & 6. Matematik & 133 & 29.11 & 12.03 & & & & \\
\hline & 7. Müzik & 45 & 24.05 & 15.01 & & & & \\
\hline & 8. Okul Öncesi & 136 & 30.44 & 10.79 & & & & \\
\hline & 9. Rehberlik & 59 & 39.12 & 12.12 & & & & \\
\hline & 10. Sinif & 199 & 40.11 & 8.13 & & & & \\
\hline & 11. Sosyal Bilgiler & 117 & 41.01 & 6.79 & & & & \\
\hline & 12. Tek./Tasarım & 79 & 26.91 & 11.29 & & & & \\
\hline & 13. Türkçe & 141 & 44.16 & 5.16 & & & & \\
\hline & 14. Yabancı Dil & 129 & 37.26 & 11.56 & & & & \\
\hline
\end{tabular}




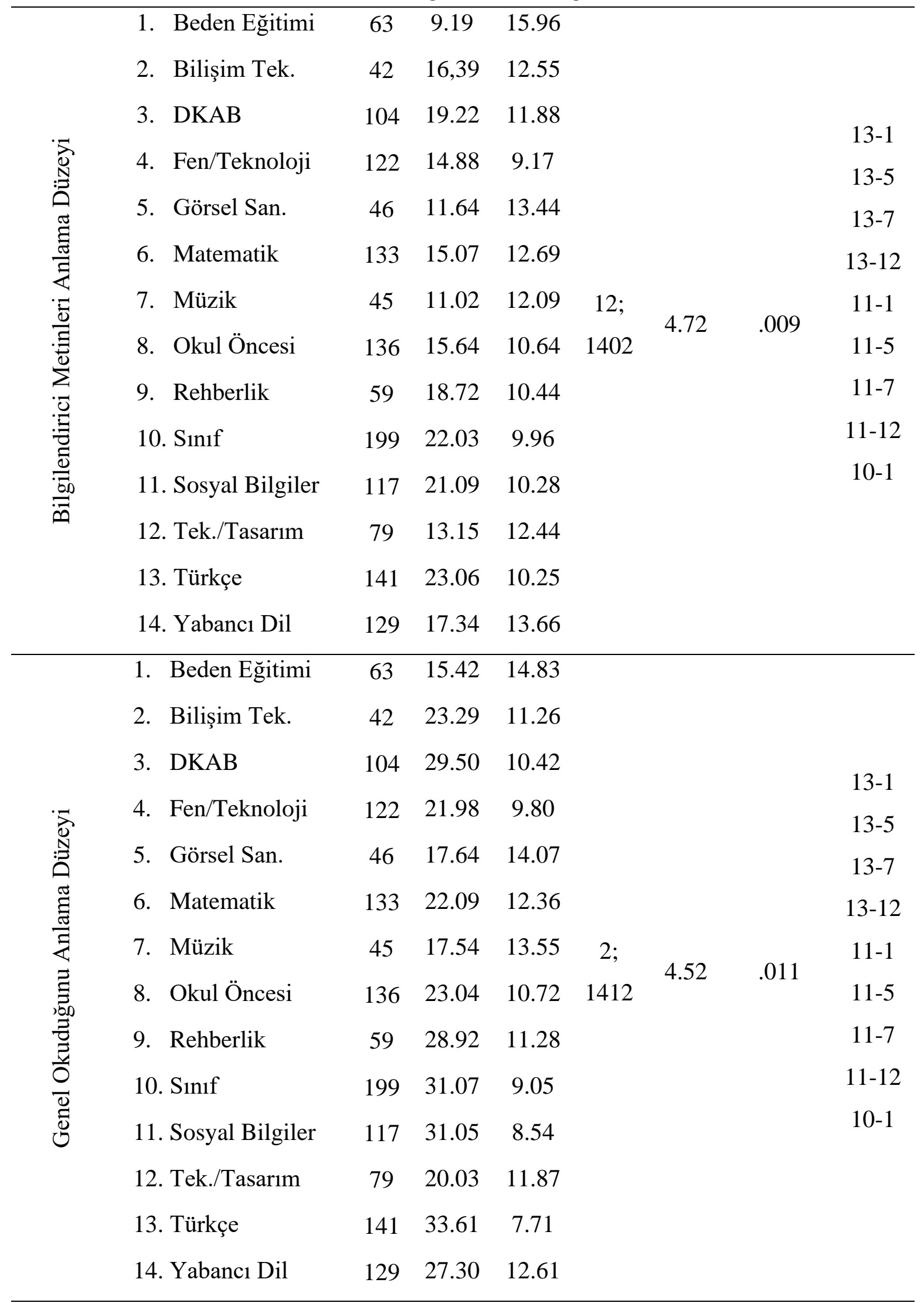

Tablo 6 incelendiğinde katılımcıların öyküleyici metinleri anlama düzeyleri branşa göre anlamlı bir şekilde değişmektedir $\left[\mathrm{F}_{(12 ; 1402)}=4.21 ; \mathrm{p}<.05\right]$. Türkçe $(\overline{\mathrm{X}}=44.16)$, Sosyal Bilgiler $(\overline{\mathrm{X}}=41.01)$ ve Sınıf öğretmenleri $(\overline{\mathrm{X}}=40.11)$; Beden Eğitimi $(\overline{\mathrm{X}}=21.65)$, Görsel 
Sanatlar ( $\bar{X}=23.64)$, Müzik ( $\bar{X}=24.05)$ ile Teknoloji ve Tasarım $(\bar{X}=26.91)$ öğretmenlerine göre öyküleyici metinleri daha çok anlamaktadırlar. Bununla birlikte Türkçe öğretmenleri öyküleyici metinleri 'çok iyi' düzeyde anlamaktadırlar. Ek olarak sosyal bilgiler, sınıf, din kültürü ve ahlak bilgisi, rehberlik ve yabancı dil öğretmenlerinin, bu metinleri ‘iyi’ düzeyde anladığı belirlenmiştir. Bilişim teknolojileri, fen ve teknoloji, görsel sanatlar, matematik, müzik, okul öncesi ile teknoloji ve tasarım branşlarında olan katılımcıların öyküleyici metinleri 'orta' düzeyde anladığı belirlenmiştir. Bu noktada beden eğitimi branşında olan katılımcıların öyküleyici metinleri 'zayıf' düzeyde anladığı bulgusu dikkat çekicidir.

Katılımcıların bilgilendirici metinleri anlama düzeyleri, branşa göre anlamlı bir farkl1lık göstermektedir $\left[\mathrm{F}_{(12 ; 1402)}=4.72 ; \mathrm{p}<.05\right]$. Türkçe $(\overline{\mathrm{X}}=23.06)$, Sosyal Bilgiler $(\overline{\mathrm{X}}=21.09)$ ve Sınıf öğretmenleri ( $\bar{X}=22.03)$; Beden Eğitimi $(\bar{X}=9.19)$, Görsel Sanatlar $(\bar{X}=11.64)$, Müzik $(\bar{X}=11.02)$ ile Teknoloji ve Tasarım $(\overline{\mathrm{X}}=13.15)$ öğretmenlerine göre bilgilendirici metinleri daha çok anlamaktadırlar. Bu noktada bilgilendirici metinleri, sınıf ve Türkçe öğretmenleri 'orta' düzeyde; diğer branşlardaki öğretmenler ise 'zayıf' düzeyde anlamaktadırlar. Beden eğitimi öğretmenlerinin okuduğunu anlama düzeyi ise 'çok zayıf' olarak belirlenmiştir.

Genel olarak okuduğunu anlama düzeyi ise katılımcıların branşlarına göre anlamlı olarak farklılaşmaktadır $\left[\mathrm{F}_{(12 ; 1402)}=4.52 ; \mathrm{p}<.05\right]$. Türkçe $(\overline{\mathrm{X}}=33.61)$, Sosyal Bilgiler $(\bar{X}=31.05)$ ve Sınıf öğretmenlerinin $(\bar{X}=31.07)$; Beden Eğitimi $(\bar{X}=15.42)$, Görsel Sanatlar $(\bar{X}=17.64)$, Müzik ( $\bar{X}=17.54)$ ile Teknoloji ve Tasarım $(\bar{X}=20.03)$ öğretmenlerine göre okuduklarını daha çok anladıkları belirlenmiştir. Ayrıca genel okuduğunu anlama düzeyi incelendiğinde, Türkçe öğretmenlerinin okuduklarını ‘iyi’ düzeyde anladıkları belirlenmiştir. Dahası bilişim teknolojileri, din eğitimi, fen, matematik, okul öncesi, rehberlik, sınıf, sosyal bilgiler ve yabancı dil öğretmenleri okuduklarını 'orta' düzeyde anlamaktadır. Beden eğitimi, görsel sanatlar, müzik ile teknoloji ve tasarım branşlarındaki öğretmenlerin ise okuduklarını 'zayıf' düzeyde anladıkları belirlenmiştir.

\section{Tartışma ve Sonuç}

$\mathrm{Bu}$ çalışma, ilk ve ortaokullarda görev yapan öğretmenlerin okuduğunu anlama düzeylerinin belirlenmesi amacıyla yapılmıştır. Araştırma sonucunda öğretmenlerin cinsiyetleri, mesleki kıdemleri, branşları ve öğrenim durumları ile okuduğunu anlama düzeyleri arasında anlamlı farklılık bulunmaktadır. Erkekler, lisansüstü mezunları ile mesleki kıdemi fazla olanlar okudukları metinleri daha fazla anlamaktadırlar. 
Araştırma sonuçlarına göre, öğretmenlerin okudukları öyküleyici metinleri anlama düzeyi cinsiyete göre değişmektedir. Erkek öğretmenlerin, kadınlara göre okudukları öyküleyici metinleri daha fazla anladıkları belirlenmiştir. Bununla birlikte benzer bir sonuç, bilgilendirici metinleri anlama düzeyinde de görülmektedir. Söz konusu durum genel olarak okuduğunu anlamada erkek öğretmenlerin daha yetkin olduğunu belirlemektedir. Alanyazında araştırmanın bu sonucunu destekleyen çalışmalar olduğu gibi farklı sonuçlara ulaşan araştırmalar da bulunmaktadır. Chavez (2001), Çam (2006) ve Karatay (2007), kadınların erkeklere göre okuduklarını anlama düzeylerinin daha yüksek olduğunu belirlemişlerdir. Buna karşın Bügel ve Buunk (1996) ile Hannon (2014), erkeklerin kadınlara göre okuduklarını anlamada daha başarılı olduğunu savunmaktadırlar. Ancak Brantmeier (2003), Coşkun (2006) ve Phakiti (2003) ise okuduğunu anlama ile cinsiyet arasında önemli bir farklılık olmadığını iddia etmektedirler. Bununla birlikte araştırmanın belki de en önemli sonucu öğretmenlerin okuduklarını "kısmen" anladıklarıdır. Araştırma kapsamında farklı zorluktaki metinlerle hazırlanan ölçekten alınabilecek en yüksek puanın 54 olduğu düşünüldügünde, erkeklerin 26.44 ve kadınların 22.56 ortalamaya sahip olması dikkat çekicidir. Buna göre erkek ve kadın öğretmenlerin, okuduklarının yarısından fazlasını anlamadıkları veya kısmen anladıkları söylenebilir. Araştırmanın bu sonucu, eğitim sistemi içinde kritik bir rol üstlenen öğretmenlerin okuduklarını anlama düzeylerinin yetersizliğini gözler önüne sermektedir.

Katılımcıların öğrenim durumları veya mezuniyet seviyeleri, okuduklarını anlama düzeylerini etkilemektedir. Araştırmanın bu sonucu alanyazındaki çeşitli araştırma sonuçlarıyla benzerlik göstermektedir (Keene ve Zimmermann, 1997; Thorndike, 1976). Böylelikle yetişkinlerin daha fazla okuma yapmaları ve okuduklarını yorumlamaları mümkün olur. Ayrıca okuduğunu anlama seviyesindeki artışla birlikte, yetişkinler okuduklarını kendi yaşantılarıyla bütünleştirebilmektedir (Thorndike, 1976). Bu araştırma alanyazındaki kuramsal bilgi birikimini doğrulamakla birlikte, eğitim seviyesindeki artışın, okuduğunu anlama düzeyinde kayda değer bir değişim oluşturacağını iddia etmektedir.

Araştırmanın bir diğer sonucu, öğretmenlerin mesleki kıdemindeki artışın, okuduklarını anlama düzeylerini de arttırmasıdır. Bu sonuç yetişkinlerin yaşlanması ve okuduklarını anlama düzeyleri arasındaki ilişkinin incelendiği farklı araştırma bulgularıyla benzerlik göstermektedir (Baker, 1984; Cain, Oakhill ve Bryant, 2004). Mesleki kıdem arttıkça öğretmenler daha fazla öğrenci ve okuma kaynağıyla karşılaşmakta, mesleki ve akademik deneyimleri artmaktadır. Deneyimdeki artış metinleri daha kolay anlamalarını da 
beraberinde getirmektedir. Ancak mesleki k1demdeki artış düşünüldüğünde, bu araştırma sonuçları ile belirginleşen okuduğunu anlama düzeyinin, öğretmenler için düşük seviyede olduğu belirlenebilir.

$\mathrm{Bu}$ araştırmanın dikkat çeken bir sonucu farklı branş öğretmenleri arasında okuduğunu anlama noktasında önemli bir ayrışmanın olduğudur. Genel okuduğunu anlama düzeyi dikkate alındığında, Türkçe öğretmenlerinin 'iyi’ bir düzeyde olması yaşamın olağan akışına uygundur. Çünkü Türkçe öğretmenleri diğer branşlara göre, metinlere daha fazla temas etmiş ve lisans döneminde okuma becerilerine yönelik eğitim almışlardır. Bunun yanında sınıf ve sosyal bilgiler öğretmenleri ile rehberlik ve din kültürü öğretmenlerinin de diğer branşlara göre daha fazla metin odaklı yetişme sürecinden geçtikleri bilinmektedir. Anılan branşlarda okuduğunu anlama düzeyinin 'orta' düzeyde olması, bu öğretmenlerden beklenen seviyenin altındadır. Ancak özellikle beden eğitimi, görsel sanatlar, müzik ile teknoloji ve tasarım branşlarındaki öğretmenlerin okuduklarını 'zayıf' düzeyde anlaması dikkat çekicidir. Lisans öğrenimi boyunca anılan branşlarda okuma becerilerine yönelik çalışmaların yapılmadığı düşünülmektedir. Okuma becerilerine ilişkin eğitim almamış öğretmenler, yalnızca kişisel girişimler ile metinlere temas etmekte ve dolayısıyla okuduklarını anlamaları yetersiz düzeyde olmaktadır. Öğretmen yetiştiren kurumların okuma becerilerine yönelik çalışmalar yapmamalarının bir sonucu olarak, öğretmenlerin okuduklarını yetersiz düzeyde anladıklarına yönelik bu araştırma bulgusu oldukça düşündürücüdür.

Okuduğunu anlama, kişinin kendi hızında bir çalışma planı yapmasıyla geliştirilebilir. Ancak öncelikle kişinin gündelik yaşamında belirgin bir zaman yönetimi yapması, okuma alışkanlığını kazanmaya istekli ve hazır olması gereklidir. Öğretmenlerin çoğunluğunun hizmet öncesi dönemde (lisans öğrenimi) okuduğunu anlama becerilerine yönelik herhangi bir eğitim almadıkları bilinmektedir. Dahası YÖK tarafından hazırlanan genel öğretmen yetiştirme müfredatında bu yönde bir ders ya da program da bulunmamaktadır. Okuduğunu anlama becerisinden yoksun bir şekilde eğitim sistemine dâhil olan öğretmenlerin çeşitli merkezi sistem sınavlarındaki (ALES, KPSS-ÖABT vb.) dil ve anlatım sorularına ilişkin yetersizlikleri, bu çalışma sonuçlarıyla benzerlik göstermektedir. Öğretmenlik lisans programlarında öğrencilerin okuma becerilerini geliştirecek, aktif okuma stratejilerini içeren kuramsal ve uygulamalı derslere yer verilmesi önerilebilir. Bunun yanında lisans döneminde genellikle çoktan seçmeli sorulara dayalı ölçme teknikleri yerine, alternatif ölçme yöntem ve tekniklerinden yararlanılması ve eleştirel düşünme becerisini geliştirmeye yönelik açık uçlu sorulara da yer verilmesi önerilebilir. Ayrıca, halen eğitim sistemi içerisinde olan 
öğretmenlerin hizmet içi eğitim faaliyetleriyle okuduklarını anlama düzeylerini geliştirecek okuma eğitimlerinin yapılması önerilebilir. Bununla birlikte gerek üniversitelerin anadil eğitimi bölümlerinden ve gerekse farklı dilbilim uzmanlarının yetkinlikleri işe koşulmalı, öğretmenlerin farklı okuma kaynaklarına erişimi, eleştirel okuma becerileri veya farklı ve güncel okuma stratejileri kazanmaları sağlanmalıdır.

Okuduğunu anlama, anadil eğitimi ve uygulamaları alanında oldukça önemli bir çalışma alanıdır. Alanyazında yer alan çalışmaların çoğunlukla öğrencilere yönelik olduğu belirlenmiştir. $\mathrm{Bu}$ noktada alanyazında yetişkinlere yönelik çalışmalara daha fazla yer verilmesi gerekmektedir.

$\mathrm{Bu}$ araştırmada öğretmenlerin okuduğunu anlama düzeyi, araştırılan örneklem grubu özelinde görünür kılınmıştır. Alanyazındaki önemli bir boşluğa işaret eden bu çalışma, okuduğunu anlama çalışmalarının çalışma yaşamına yönelmesi açısından önem taşımaktadır. $\mathrm{Bu}$ araştırma Ankara ilinde çalışan sınırlı bir grup öğretmen örneklemi üzerinde yürütülmüştür. Araştırma verileri 2016-2019 yılları arasında toplanmıştır. Toplumsal ve ekonomik değişiklikler ile eğitim sisteminde oluşabilecek beklenmedik durumlar, okuduğunu anlama olgusuna ilişkin verilerin değişmesine neden olabilir ve araştırmanın güncelliğini geçersiz kılabilir. Ayrıca bu araştırmada örneklem seçimi, sonuçların genellenebilir olmasını sağlayacak şekilde geniş tutulsa da farklı illerin de dâhil olduğu daha büyük örneklemler üzerinde çalışılması bundan sonra yapılacak araştırmalar için önerilebilir. İleride yapılacak çalışmalarda örneklemin, farklı sektörlerde çalışanları da içerecek şekilde genişletilmesi önerilebilir.

Okuduğunu anlama düzeyinin ölçülmesi, ölçekte yer alan metin türü ve metne ilişkin soru tipinden (çoktan seçmeli, açık uçlu vb.) etkilenmektedir. Bu araştırma, Bloom taksonomisine uygun olarak hazırlanmış farklı zorluk seviyelerindeki bilgilendirici ve öyküleyici metinlerden ve çoktan seçmeli sorulardan oluşan bir ölçme düzeneği kullanılarak yapılmıştır. İleride yapılacak çalışmaların özellikle katılımcıların yorumlama becerilerini de ölçen, açık uçlu sorulara yer verecek ölçme araçları ile gerçekleştirilmesi önerilebilir. Ayrıca ileride yapılacak araştırmalarda hane halkı gelir düzeyi, mezun olunan fakülte veya yüksekokul gibi çevresel koşulların dâhil edilmesi önerilebilir. Böylelikle okuduğunu anlama üzerinde farklı değişkenlerin etkileri daha iyi anlaşılabilir. Okuduğunu anlama araştırmalarında veri toplanması ve ölçülmesinin görece zorluklar içermesi sebebiyle ileride yapılacak araştırmaların karma araştırma veya nitel araştırma teknikleri kullanılarak desenlenmesi ve hatta farklı yılları içine alan boylamsal araştırmalar yapılması önerilebilir. 


\section{Kaynakça}

Aktaş, Ş. (2000). Roman sanatı ve roman incelemesine giriş. Ankara: Akçağ.

Akyol, H. (2011). Yeni programa uygun Türkçe ögrretim yöntemleri. Ankara: Pegem.

Al-Homoud, F., \& Schmitt, N. (2009). Extensive reading in a challenging environment: A comparison of extensive and intensive reading approaches in Saudi Arabia. Language Teaching Research, 13(4), 383-401.

Baker, L. (1984). Spontaneous versus instructed use of multiple standards for evaluating comprehension: Effects of age, reading proficiency, and type of standard. Journal of Experimental Child Psychology, 38(2), 289-311.

Baltacı, A. (2017). Okul müdürlerinin okuma alışkanlıkları ve okuduğunu anlama düzeyleri. Eğitim ve Toplum Araştırmaları Dergisi, 4(2), 1-32.

Bamberger, R. (1976). Literature and development in reading. New Horizons in Reading, 5(1), 60-65.

Başaran, M. (2013). Okuduğunu anlamanın bir göstergesi olarak akıcı okuma. Kuram ve Uygulamalarda Ĕ̈itim Bilimleri, 13(4), 2277-2290.

Bell, T. (2001). Extensive reading: Speed and comprehension. Reading Matrix: An International Online Journal, 1(1), 1-13.

Berger, P. L. \& Luckmann, T. (2008). Gerçekliğin sosyal inşası: Bir bilgi sosyolojisi incelemesi. İstanbul: Paradigma.

Brantmeier, C. (2003). Does gender make a difference? Passage content and comprehension in second language reading. Reading in a Foreign Language, 15(1), 1-27.

Bügel, K., \& Buunk, B. P. (1996). Sex differences in foreign language text comprehension: The role of interests and prior knowledge. The Modern Language Journal, 80(1), 1531.

Büyüköztürk, Ş. (2017). Sosyal bilimler için veri analizi el kitabı. Ankara: Pegem.

Cain, K., Oakhill, J., \& Bryant, P. (2004). Children's reading comprehension ability: Concurrent prediction by working memory, verbal ability, and component skills. Journal of Educational Psychology, 96(1), 31-42. 
Can, R., Türkyılmaz, M., \& Karadeniz, A. (2010). Ergenlik dönemi öğrencilerinin okuma alışkanlıkları. Ahi Evran Üniversitesi Eğitim Fakültesi Dergisi, 11(3), 1-21.

Chall, J. S., Jacobs, V. A., \& Baldwin, L. E. (2009). The reading crisis: Why poor children fall behind. Boston: Harvard University Press.

Chavez, M. (2001). Gender in the language classroom. New York: McGraw Hill.

Coelho, C. L. G., \& Correa, J. (2017). Reading comprehension: Cognitive abilities and types of text. Psico, 48(1), 40-49.

Cohen, J. (1968). Weighted kappa: Nominal scale agreement provision for scaled disagreement or partial credit. Psychological Bulletin, 70(4), 213-221.

Coiro, J., \& Dobler, E. (2007). Exploring the online reading comprehension strategies used by sixth-grade skilled readers to search for and locate information on the Internet. Reading research quarterly, 42(2), 214-257.

Çam, B. (2006). Illköğretim öğrencilerinin görsel okuma düzeyleri ile okuduğunu anlama, eleştirel okuma ve Türkçe dersi akademik başarıları arasındaki ilişki. Yayımlanmamış yüksek lisans tezi, Osmangazi Üniversitesi, Eskişehir.

Çeçen, M. A. (2011). Yazma eğitimi açısından metin bilgisi. In M. Özbay (Ed.), Yazma Ĕ̈itimi (pp. 127-146). Ankara: Pegem.

Çelenk, S., \& Çalışkan, M. (2004). Bazı sosyoekonomik faktörlerin okuduğunu anlama başarısına etkisinin incelenmesi. Çăgdaş Ĕ̈itim Dergisi, 309, 24-33.

Davey, B. (1983). Think aloud: Modeling the cognitive processes of reading comprehension. Journal of Reading, 27(1), 44-47.

Demir, Y. (2012). The effect of background knowledge and cultural nativization on reading comprehension and vocabulary inference. Journal of Educational \& Instructional Studies in the World, 2(4), 188-198.

Durkin, D. (1978). What classroom observations reveal about reading comprehension instruction. Reading Research Quarterly, 11(3), 481-533.

Ehri, L. C. (2005). Learning to read words: Theory, findings, and issues. Scientific Studies of reading, $9(2), 167-188$.

Fleiss, J. L. (1971). Measuring nominal scale agreement among many raters. Psychological Bulletin, 76(5), 378. 
Friedman, N. P., \& Miyake, A. (2004). The reading span test and its predictive power for reading comprehension ability. Journal of Memory and Language, 51(1), 136-158.

Günay, D. (2007). Metin bilgisi. İstanbul: Multilangual.

Habermas, J. (2001). Illetişimsel eylem kuramı. (Çev: M. Tüzel). İstanbul: Kabalcı.

Hannon, B. (2014). Are there gender differences in the cognitive components of adult reading comprehension? Learning and Individual Differences, 32(2), 69-79.

Heidegger, M. (2002). Hümanizm üzerine mektup: Hümanizmin özü. (Çev: A. Aydoğan). İstanbul: İz Yayıncilık.

Hegarty, P., \& Golden, A. M. (2008). Attributional beliefs about the controllability of stigmatized traits: antecedents or justifications of prejudice? Journal of Applied Social Psychology, 38(4), 1023-1044.

Hock, M., \& Mellard, D. (2005). Reading comprehension strategies for adult literacy outcomes. Journal of Adolescent \& Adult Literacy, 49(3), 192-200.

Hsueh-Chao, M. H., \& Nation, P. (2000). Unknown vocabulary density and reading comprehension. Reading in a foreign language, 13(1), 403-430.

Just, M. A., \& Carpenter, P. A. (1980). A theory of reading: From eye fixations to comprehension. Psychological Review, 87(4), 329-342.

Karatay, H. (2007). İlköğretim Türkçe ögrretmeni adaylarının okuduğunu anlama becerileri üzerine alan araştırması. Yayımlanmamış doktora tezi, Gazi Üniversitesi, Ankara.

Kartal, E., \& Özteke, H. Ç. (2010). İlköğretim öğrencilerinin okuduklarını anlama ve anlatma düzeylerinin belirlenmesi. The Journal of International Social Research, 3 (11), 372380.

Keene, E. O., \& Zimmermann, S. (1997). Mosaic of thought: Teaching comprehension in a reader's workshop. Portsmouth: Heinemann Inc.

Keenan, J. M., Betjemann, R. S., \& Olson, R. K. (2008). Reading comprehension tests vary in the skills they assess: Differential dependence on decoding and oral comprehension. Scientific Studies of Reading, 12(3), 281-300.

Krippendorff, K. (1995). On the reliability of unitizing continuous data. Sociological Methodology, 4(2), 47-76. 
Kurnaz, H., \& Akaydın, Ş. (2015). Türkçe öğretmeni adaylarının bilgilendirici ve öyküleyici metinleri özetleme becerileri. Erzincan Üniversitesi Sosyal Bilimler Enstitüsü Dergisi, 9(2), 141-156.

Landis, J. R., \& Koch, G. G. (1977). The measurement of observer agreement for categorical data. Biometrics, 3(2), 159-174.

Meyer, B. J., Brandt, D. M., \& Bluth, G. J. (1980). Use of top-level structure in text: Key for reading comprehension of ninth-grade students. Reading Research Quarterly, 72-103.

Odabaş, H., Odabaş, Y., \& Polat, C. (2008). Üniversite öğrencilerinin okuma alışkanlığı: Ankara Üniversitesi örneği. Bilgi Dünyası, 9(2), 431-465.

Pearson, P. D. (1991). Developing expertise in reading comprehension: what should be taught? How should it be taught? (Report No. 512). Illinois, IL: U.S. Center for the Study of Reading.

Phakiti, A. (2003). A closer look at gender and strategy use in L2 reading. Language Learning, 53(4), 649-702.

Rasinski, T. V. (2000). Commentary: Speed does matter in reading. The Reading Teacher, 54(2), 146-151.

Fuchs, D., \& Fuchs, L. S. (2005). Peer-assisted learning strategies: Promoting word recognition, fluency, and reading comprehension in young children. The Journal of Special Education, 39(1), 34-44.

Saracaloğlu, A. S., \& Karasakaloğlu, N. (2011). Sınıf öğretmeni adaylarının okuduğunu anlama düzeyleri ile çalışma ve öğrenme stratejilerinin çeşitli değişkenler açısından incelenmesi. Ĕgitim ve Bilim, 36(161), 98-115.

Shanker, J. L., \& Ekwall, E. E. (2009). Locating and correcting reading difficulties. New York: Pearson Inc.

Suna, Ç. (2006). İlköğretim öğrencilerinin okuma ilgi ve alışkanlıklarını etkileyen etmenlerin analitik olarak incelenmesi ve değerlendirilmesi. Yayınlanmamış yüksek lisans tezi, Anadolu Üniversitesi, Eskişehir.

Tayşi, E. K. (2007), Illköğretim 5. ve 8. sinıf öğrencilerinin hikâye ve deneme türü metinlerindeki okuduğunu anlama becerilerinin karşılaştırılması (Kütahya ili örneği). Yayımlanmamış yüksek lisans tezi, Gazi Üniversitesi, Ankara. 
Temizkan, M. (2009). Metin türlerine göre okuma eğitimi. Ankara: Nobel.

Thorndike, R. (1976). Reading comprehension in fifteen countries. New Horizons in Reading, 11(2), 500-507.

Topuzkanamış, E., \& Maltepe, S.(2010). Öğretmen adaylarının okuduğunu anlama ve okuma stratejilerini kullanma düzeyleri. TÜBAR, 27, 655-677.

Ungan, S. (2008), Türkiye'de kitap okuma: okuma alışkanlığımızın kültürel altyapısı. Gaziantep Üniversitesi Sosyal Bilimler Dergisi, 7(1), 218-228.

Üründü, V. (2011). 6-8. sinıf Türkçe ders kitaplarının tema ve metin türü açısından incelenmesi. Yayınlanmamış yüksek lisans tezi, İnönü Üniversitesi, Malatya.

Vega, M. (1996). The representation of changing emotions in reading comprehension. Cognition \& Emotion, 10(3), 303-322.

Wigfield, A., Gladstone, J. R., \& Turci, L. (2016). Beyond cognition: Reading motivation and reading comprehension. Child Development Perspectives, 10(3), 190-195.

Willis, A. I. (2012). Reading comprehension research and testing in the US: Undercurrents of race, class, and power in the struggle for meaning. New York: Routledge.

Yamashita, J. (2008). Extensive reading and development of different aspects of L2 proficiency. System, 36(4), 661-672.

Yılmaz, B., Köse, E., \& Korkut, Ş. (2009). Hacettepe Üniversitesi ve Bilkent Üniversitesi öğrencilerinin okuma alışkanlıkları üzerine bir araştırma. Türk Kütüphaneciliği, 23(1), $22-51$. 